\author{
M. V. Zakhartsev · B. De Wachter · F. J. Sartoris \\ H. O. Pörtner · R. Blust
}

\title{
Thermal physiology of the common eelpout (Zoarces viviparus)
}

\begin{abstract}
We investigated the temperature dependence of some physiological parameters of common eelpout (Zoarces viviparus) from different locations (North Sea, Baltic Sea and Norwegian Sea) on acclimation temperature $\left(3{ }^{\circ} \mathrm{C}\right.$ and $\left.12{ }^{\circ} \mathrm{C}\right)$ and acute temperature variation. The lethal limit of $12{ }^{\circ} \mathrm{C}$-acclimated eelpout was determined as the critical thermal maximum [loss of equilibrium (LE) and onset of muscular spasms (OS)] and it was found to be $26.6^{\circ} \mathrm{C}$ for $\mathrm{LE}$ and $28.8^{\circ} \mathrm{C}$ for OS for all populations. However, these parameters do not have any relevant ecological interpretation. We therefore investigated the effect of gradually increased water temperature on standard metabolic rate (measured as resting oxygen consumption $\mathrm{Mo}_{2}$ ) and critical oxygen concentration $\left(\left[\mathrm{O}_{2}\right]_{\mathrm{c}}\right)$ of eelpouts. Acclimation to low temperature $\left(3{ }^{\circ} \mathrm{C}\right)$ resulted in partial compensation of $\mathrm{Mo}_{2}$, paralleled by a decrease of activation energy for $\mathrm{Mo}_{2}$ (from $82 \mathrm{~kJ} \mathrm{~mol}^{-1}$ at $12{ }^{\circ} \mathrm{C}$ to about $50 \mathrm{~kJ} \mathrm{~mol}^{-1}$ at $3{ }^{\circ} \mathrm{C}$ ) in North Sea and Baltic Sea eelpouts. At the same time, Norwegian eelpout showed no acclimation of oxygen demand to warm temperature $\left(12{ }^{\circ} \mathrm{C}\right)$ at all. The scope for eelpout aerobic metabolism shrank considerably with increased acclimation temperature, as $\left[\mathrm{O}_{2}\right]_{\mathrm{c}}$ approached water oxygen concentrations. At $22.5 \pm 1{ }^{\circ} \mathrm{C}$ the $\left[\mathrm{O}_{2}\right]_{\mathrm{c}}$ reached air saturation, which is equivalent to the upper critical temperature $\left(T \mathrm{c}_{\mathrm{II}}\right)$ and at this temperature the aerobic scope for the metabolism completely disappeared. In line with previous insight, the comparative analysis of the temperature dependence of
\end{abstract}

Communicated by G. Heldmaier

M. V. Zakhartsev $(\bowtie) \cdot$ B. De Wachter $\cdot$ R. Blust

Department of Biology, University of Antwerp,

University of Antwerp-RUCA, Groenenborgerlaan 171, 2020 Antwerp, Belgium

E-mail: Maxim.Zakhartsev@ua.ac.be

Tel.: + 32-3-2180347

Fax: + 32-3-2180497

F. J. Sartoris · H. O. Pörtner

Marine Biology/Ecological Physiology,

Alfred-Wegener-Institute, Bremerhaven, Germany
$\mathrm{Mo}_{2}$ of Z. viviparus from different populations suggests that a pejus (sub-critical) temperature for this species is about $13-15{ }^{\circ} \mathrm{C}$. In conclusion, the capacity to adjust aerobic metabolism relates to thermal tolerance and the bio-geographical distribution of the species. Global warming would thus be likely to cause a shift in the distribution of this species to the North.

Keywords Critical oxygen concentration - Critical temperature $\cdot$ Aerobic scope $\cdot$ Pejus temperature $\cdot$ Geographical distribution

Abbreviations CTMax critical thermal maximum - Fiv factor of inside volume $G_{T}$ total oxygen conductance $\cdot$ $L E$ loss of equilibrium $\cdot L T_{50}$ time period of exposure when mortality reaches $50 \% \cdot M_{O 2}$ rate of oxygen consumption $\cdot \mathrm{M}_{\mathrm{O}_{2}}{ }^{\circ}$ rate of oxygen consumption at $0{ }^{\circ} \mathrm{C} \cdot\left[\mathrm{O}_{2}\right]_{c}$ critical oxygen concentration $\cdot O S$ onset of muscular spasms $\cdot T c$ critical temperature $\cdot T c_{l l}$ upper critical temperature $\cdot T p$ pejus temperature

\section{Introduction}

Aquatic ectotherms with a wide latitudinal distribution are interesting animal models to study the mechanisms of temperature adaptation. A wide latitudinal distribution implies that the species is exposed to significantly different temperature regimes in various sections of its natural habitat. Usually, such species are also exposed to considerable seasonal temperature variations, and are called eurythermal (Precht et al. 1973). Comparative study between populations or species from various climates should allow us to identify the physiological parameters crucial for the bio-geographical distribution of a species.

There are several criteria to evaluate the thermal limits of a species: (1) lethal temperatures and the time period of exposure, when mortality reaches $50 \%\left(\mathrm{LT}_{50}\right)$, (2) the critical thermal maximum (CTMax), which is the temperature at which locomotory activity becomes 
disorganized and the animal loses the ability to escape from the lethal conditions, (3) incipient lethal temperature (ILT), which is the temperature at which median $\mathrm{LT}_{50}$ is no longer dependent on exposure time (for review of these criteria see (Cossins and Bowler 1987). However, these criteria have only descriptive character and cannot provide us with a clear mechanistic understanding of limited thermal tolerance (Portner et al. 1998; Portner 2001).

There is a definite correlation between adaptation temperature and both the denaturation temperature of enzymes (Johnston 1985; Johnston and Walesby 1977; Sokolova and Portner 2001) and the temperature of membrane phase transitions (O'Brien et al. 1991). However, these temperatures do not explain the limitation of thermal tolerance. It is obvious that thermal death happens at temperatures that are much lower than the denaturation temperatures of any proteins or membrane phase transitions.

According to a recent concept of thermal adaptation and limitation (Portner et al. 1998, 2001; Portner 2002a) thermal tolerance is limited by oxygen availability to mitochondria. Accordingly, the capacity of oxygen delivery systems (oxygen uptake and distribution by ventilation and circulation) sets the limits of thermal tolerance (Portner 2002a). At critical temperatures $(T \mathrm{c})$ aerobic scope disappears and transition to an anaerobic mode of mitochondrial metabolism and progressive insufficiency of cellular energy levels occurs (Van Dijk et al. 1999). These processes define the reasons for thermal death and the critical temperature limits for survival.

Recently, the Tc-concept has been improved by the introduction of the concept of pejus temperatures into thermal physiology ( $T$ p ; pejus - getting worse) (Frederich and Portner 2000; Portner 2002a). The term pejus temperature is based on Shelford's law of tolerance (Shelford 1913) and it represents a sub-critical temperature, where thermal limitation already sets in at the transition from optimal to sub-critical (pejus) range, due to a limitation in aerobic scope. This limitation can be characterized by the onset of a decrease in aerobic scope for metabolism and, in a crustacean, was reflected by a drop of arterial $\mathrm{PO}_{2}$ due to capacity limited ventilatory and cardiac performance (Frederich and Portner 2000).

Zoarces viviparus is one of the species with a latitudinal distribution ranging from the English Channel to the Russian White Sea, including the British Isles, the North Sea, the Baltic Sea, and the Norwegian coastline. Due to its wide range of latitudinal distribution, ubiquity and simple aquarium maintenance, Z. viviparus became one of the most convenient model species for environmental biomonitoring programs (BEEP'; $\mathrm{ESB}^{2}$ )

\footnotetext{
${ }^{1}$ For information on the BEEP project, please see: http:// beep.1ptc.u-bordeaux.fr/_WP4.asp

${ }^{2}$ For information on the ESB project, please see:http://www.umweltbundesamt.de/uba-info-daten-e/daten-e/um. weltprobenbankdes-bundes.htm
}

and also for studies of the mechanisms of temperature adaptation in eurythermal marine ectothermic animals $\left(\mathrm{CLICOFI}^{3}\right)$. The goal of this article is to describe the thermal tolerance of different populations of $Z$. viviparus adopting the recent developments in the concepts of thermal tolerance.

\section{Materials and methods}

\section{Eelpout}

Common eelpouts (Z. viviparus Linnaeus, 1758) were collected at different locations: North Sea (island Helgoland, Germany); Baltic Sea (Kiel Bight, Germany); Norwegian Sea (Stavanger, Norway). The typical environmental conditions for those locations are listed in Table 1.

\section{Acclimation}

Upon delivery from the field, the fishes were allowed to recover in flow-through aquaria for at least 3 weeks under conditions equal to those in the field (temperature, salinity and light regime). Then fishes were divided into two groups and each was acclimated to $3{ }^{\circ} \mathrm{C}$ or $12{ }^{\circ} \mathrm{C}$ for at least 4 weeks. During recovery or acclimation, feeding was ad libitum with meat of cut shrimp (Pandalus borealis) or fish (Gobius gobius, $0.62 \pm 0.21 \mathrm{~g}$ ) once a week.

\section{Critical thermal maximum}

CTMax is the thermal point at which locomotory activity becomes disorganized and animals lose the ability to escape from lethal conditions. Either loss of equilibrium (LE) or onset of spasms (OS) defines the CTMax. According to common terminology applied by Lutterschmidt and Hutchison (1997a), the LE is the thermal point at which fish show inverted swimming; the OS is the thermal point at which fish shows muscular spasms, which are disorganized and high-frequency muscular movements, rigidity of the pectoral fins and, especially, high-frequency quivering of the opercula. In fact, rapid quivering of the opercula serves as a clear and reliable marker for OS. Body shuddering, gill distension and mouth gaping usually accompany these muscular spasms in fish.

The sequence of events for fish during an acute temperature increase is: agitated behaviour $\rightarrow$ loss of equilibrium $\rightarrow$ onset of spasms $\rightarrow$ heat rigor $\rightarrow$ coma $\rightarrow$ death. The difference (in degrees) between the temperatures of OS and death is very short, moreover, the tolerance to being exposed to temperatures above OS is very limited (several seconds), therefore, the animal must be returned to the acclimation temperature as fast as possible (Lutterschmidt and Hutchison 1997a).

Every single fish (Baltic $n=7$; North Sea $n=5$ ) was placed into individual flow-through aquaria (3 1) with water conditions according to acclimation parameters. The fish were isolated from visual contact. Fishes were exposed to an acute, highly precise increase in water temperature (starting from acclimation temperatures) by $1.0{ }^{\circ} \mathrm{C} \mathrm{min}^{-1}$. The water temperature increment was elicited by adding heated water at $60{ }^{\circ} \mathrm{C}$. The water was thoroughly mixed by intensive air bubbling in order to secure uniform warming of the water mass. At OS, the temperature was immediately (within 20-30 s) decreased back to acclimation temperature by replacing "hot" with "cold" water, then the fishes were allowed to recover until the next morning. During the determination of CTMax, water

\footnotetext{
${ }^{3}$ For information on the CLICOFI project, please see: http:// www.awi-bremerhaven.de/ECOLOGY/CLICOFI/
} 
Table 1 Average levels of salinity and water temperature at different locations (averaged for the water column between $0 \mathrm{~m}$ and $10 \mathrm{~m}$ )

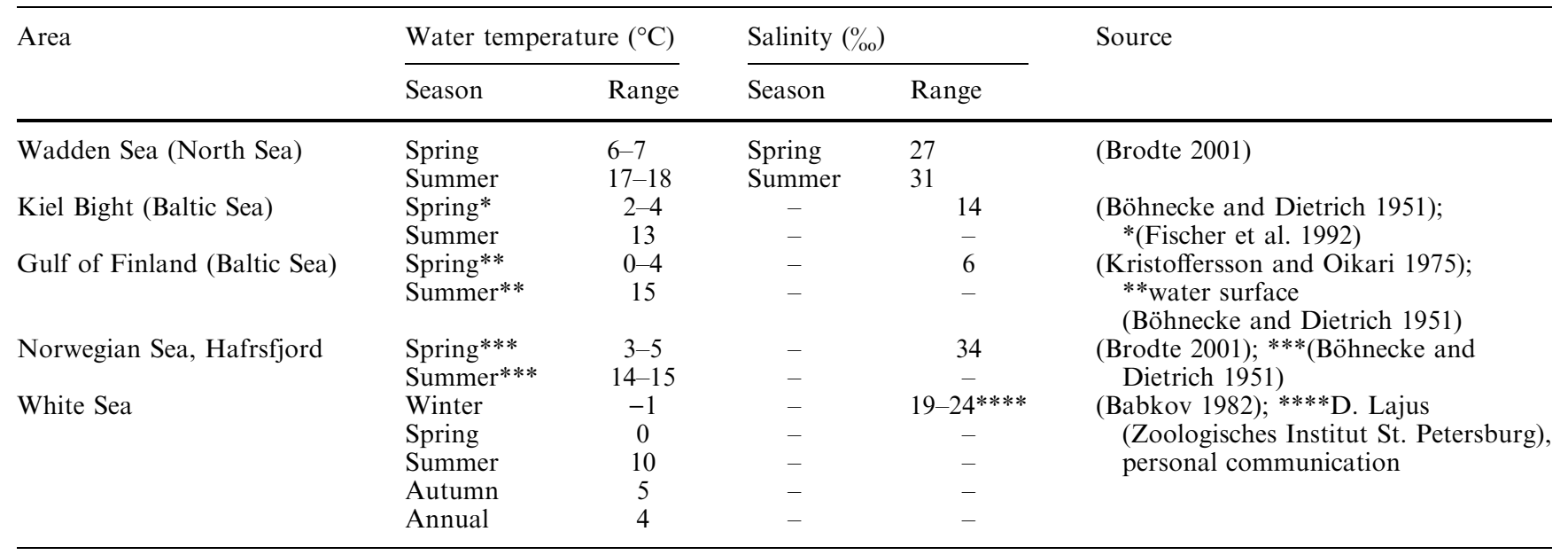

Fig. 1 A Schematic drawing of the closed respirometer: 1 respiration chamber; 2 cell of oxygen probe (WTW CellOx325); 3 cell for water sampling; 4 volume compensator with variable inside volume; $V_{1}$ and $V_{2}$ three-position valves [to connect (loop) or disconnect the respirometer]; $\mathrm{O}_{2}$-meter oxygen meter (WTW Oxi325); $T{ }^{\circ} \mathrm{C}$-controller external thermostat; $P C$ personal computer for data collection; $\rightarrow$ direction of water flow. The drawing is depicting the respirometer in the "disconnected" state. B Schematic drawing of the flow-through respirometer: 1 respiration chamber; 2 fast connector (makes the setup either in connected or disconnected state); 3 cell of fibre-optic oxygen microsensor (PreSens, Germany); 4 peristaltic pump; $\mathrm{O}_{2}$-meter oxygen meter MICROX8 (PreSens, Germany); $T^{\circ} \mathrm{C}$-controller external thermostat; $P C$ personal computer for data collection; $\rightarrow$ direction of the water flow. Combination of the aquarium pump and the peristaltic pump provides accurate control of the flow rate through the respirometer. The drawing is depicting the system in the "connected" state oxygenation at all times was no less than $90-95 \%$ of full saturation. Measurements were repeated for 5 consecutive days. There was no feeding during the experiment.

\section{Respirometry}

\section{Closed respirometry}

For an analysis of critical oxygen tensions (carried out at RUCA in Antwerp) the fishes were placed into closed respirometers, which could be in two states: "connected" and "disconnected" (Fig. 1A). Prior to handling the fishes were treated with $40 \mathrm{mg}^{-1}$ MS222 (Ross and Ross 1999) for 3-5 min to initiate soft sedation (Stoskopf 1992) and to prevent handling stress. Fishes were allowed to recover for the next $24 \mathrm{~h}$. The inside volume of the respirometer was evaluated for each individual fish using the factor of inside volume (Fiv; Eqn 1).
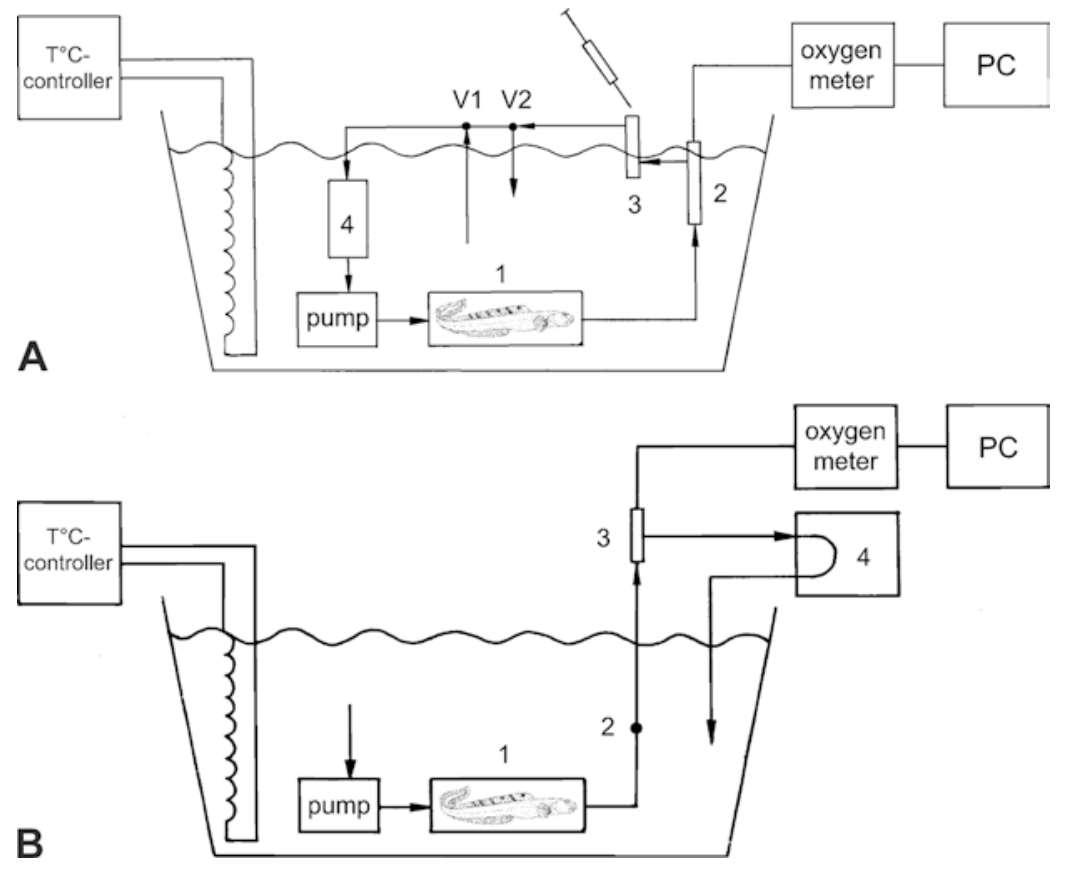
$F_{i v}=\frac{V_{i n}-w_{f}}{w_{f}}$

where: Fiv factor of inside volume, $V_{i n}$ overall inside volume of the respirometer $(\mathrm{ml})$ and $w_{f}$ weight of fish $(\mathrm{g})$. For eelpout the optimum Fiv was $14-16$ at $12{ }^{\circ} \mathrm{C}$, in this case, eelpouts reached extreme hypoxia (10-25 $\mu \mathrm{M}$ oxygen) within 3-3.5 h upon closure of the respirometer. The Fiv had to be increased with any temperature increment $(\Delta T)$ by $2.5 \%$ per degree.

$V_{\text {in }}=(\Delta T)=V_{\text {in }}^{\circ} \exp (0.025 \Delta T)$

$V_{\text {in }}^{\circ}=15 w_{f}\left(\right.$ at $\left.12^{\circ} \mathrm{C}\right)$

Increases of the inside volume of the respirometer by the volume compensator (No. 4 in Fig. 1A) allowed the offsetting of the temperature effect on the time taken to reach extreme hypoxia.

The water temperature was raised by $1{ }^{\circ} \mathrm{C}$ per 2 days in the temperature range between $12{ }^{\circ} \mathrm{C}$ and $18.5^{\circ} \mathrm{C}$. The measurements were carried out only during daytime. The measurement procedure consisted of two phases: measurement (for 3-3.5 h) and recovery (for 44.5-45 h), the latter being accompanied by the temperature increment $\left(1{ }^{\circ} \mathrm{C} 2\right.$ days $\left.^{-1}\right)$. This protocol for the rate of temperature change was chosen to avoid the overlap/combination of two lifelimiting factors: regular exposure to hypoxia and acute temperature change.
Eight oxygen meters Oxi325 with probes CellOx325 (WTW, Germany) were calibrated with solutions containing oxygen at $0 \%$ (saturated solution of $\mathrm{Na}_{2} \mathrm{SO}_{3}$ ) and $100 \%$ air saturation (aquarium water). All calibration solutions were temperature equilibrated in the experimental tank. The calibration procedure was carried out each time right before the onset of measurements.

To start the measurements the respirometers were "connected" (Fig. 1A). We used eight respirometers (seven with fishes and the eighth as a blank). The internal concentration of oxygen was monitored as a function of time (with a recording interval of once per minute, Windmill Logger V4.06, Windmill Software). The measurements were continued until the fish had reached extremely hypoxic conditions $\left(\left[\mathrm{O}_{2}\right] \approx 10-25 \mu \mathrm{M}\right)$, then the respirometers were "disconnected" to allow normoxic water from the ambient aquarium to flush the respirometer, and the fishes were allowed to recover until the next measurement.

The rate of oxygen consumption $\left(\mathrm{Mo}_{2}\right)$, evaluated from 10-min intervals, was calculated according to formula:

$\left(\mathrm{Mo}_{2}\right)_{i}=\frac{\left(\left[\mathrm{O}_{2}\right]_{i}-\left[\mathrm{O}_{2}\right]_{i+10}\right) \times\left(V_{i n}-w_{f}\right) \times 10^{-3}}{\left(t_{i+10}-t_{i}\right) \times w_{f}}$

[ $\mu$ moles $\left.\min ^{-1} \mathrm{~g}^{-1}\right]$; where: $\left(\left[\mathrm{O}_{2}\right]_{\mathrm{i}+10}\right.$ ? $\left.\left[\mathrm{O}_{2}\right]_{\mathrm{i}}\right)$ change in oxygen concentration inside the respirometer within $10 \mathrm{~min}(\mu \mathrm{M}) ; \mathrm{V}_{\text {in }}$ overall inside volume of the respirometer $(\mathrm{ml}) ;\left(t_{i}+10-t_{i}\right)$ time interval $(\mathrm{min})$, here $10 \mathrm{~min} ; \mathrm{w}_{\mathrm{f}}$ weight of the fish $(\mathrm{g}) . \mathrm{Mo}_{2}$ was calculated for
Fig. 2 A Typical data set obtained during measurements of the critical oxygen concentration $\left(\left[\mathrm{O}_{2}\right]_{c}\right)$ and the rate of oxygen consumption $\left(\mathrm{Mo}_{2}\right)$ in closed respirometers for Baltic eelpout acclimated to $12{ }^{\circ} \mathrm{C}$. Conditions of the measurements were: different water temperatures, the rate of temperature change was $1{ }^{\circ} \mathrm{C}$ per 2 days; water salinity was $17 \%$; measurements always lasted about $3-3.5 \mathrm{~h}$; the body weight of the fish was $41.4 \mathrm{~g}$. B Typical data set obtained during $\mathrm{Mo}_{2}$ measurements using flow-through respirometry. The measurements consist of four phases: 1 baseline recordings; 2 adjustment of the flow rate; 3 recording of the oxygen concentration in excurrent water; 4 recording of the baseline. Connecting or disconnecting the respirometer occurred with the fast connector (2, in Fig. 1b). The oxygen concentration at the respirometer outlet was always set to within $100-75 \%$ (by means of adjusting the flow rate in phase 2 in order to avoid hypoxia exposures)
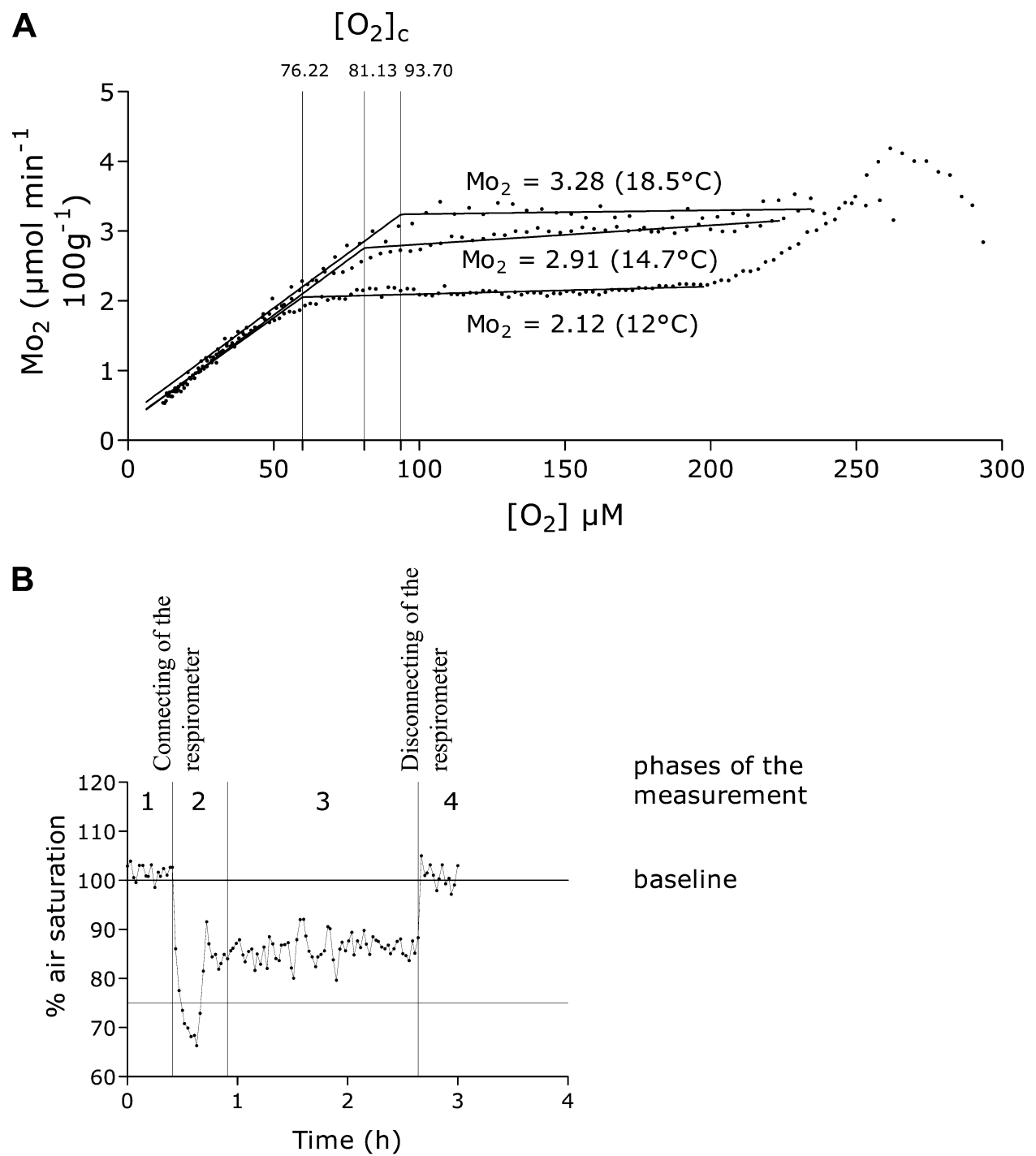

phases of the
measurement

baseline 
any moment $\mathrm{i}\left[\left(\mathrm{Mo}_{2}\right)_{\mathrm{i}}\right]$ from $\mathrm{i}=1$ to $\mathrm{i}=\max$. We used 1-min intervals to record the data, but $\mathrm{Mo}_{2}$ was calculated for 10-min intervals. The blank $\mathrm{Mo}_{2}$ was subtracted from the fish's $\mathrm{Mo}_{2}$. $\left(\mathrm{Mo}_{2}\right)_{\mathrm{i}}$ was plotted against the averaged $\left[\mathrm{O}_{2}\right]$ for the corresponding 10 min interval $\left[\mathrm{O}_{2}\right]_{\mathrm{i}}$ (Fig. $2 \mathrm{~A}$ ). $\mathrm{Mo}_{2}$ was expressed in terms of micromoles of oxygen consumed within a minute per gram of fish body and normalized to the rate per $100 \mathrm{~g}$ fish body [ $\mu$ moles $\mathrm{min}^{-1}$ $100 \mathrm{~g}^{-1}$. The basal metabolic rate was calculated as the averaged $\mathrm{Mo}_{2}$ from the horizontal part of the graph (Fig. 2A) and expressed in the same units.

\section{Critical oxygen concentration and basal metabolic rate}

The critical oxygen concentration $\left(\left[\mathrm{O}_{2}\right]_{\mathrm{c}}\right)$ not only depicts the transition from oxyregulation to oxyconformity during progressive hypoxia, but also the point of transition to anaerobic metabolism (Portner and Grieshaber 1993). Therefore, the $T_{\mathrm{c}}$ should be reached when the rise in $\left[\mathrm{O}_{2}\right]_{c}$ during warming reaches oxygen concentrations of air-saturated water. $\left[\mathrm{O}_{2}\right]_{\mathrm{c}}$ was calculated as the break-point of the graph depicting the $\mathrm{Mo}_{2}-\left[\mathrm{O}_{2}\right]$ dependence (Fig. $2 \mathrm{~A}$ ) by means of two-phase linear regression analysis (GraphPad Prism V3.02, GraphPad Software) (Motulsky 1999; Yeager and Ultsch 1989). The $\left[\mathrm{O}_{2}\right]_{c}$ was expressed in micromoles $\mathrm{O}_{2}$ per litre of ambient water.

Flow-through respirometry

For an analysis of temperature-dependent changes in oxygen consumption (carried out at the AWI, Bremerhaven) fishes $(n=8)$ were placed into individual flow-through respiration chambers and were allowed to recover from the handling procedure for the next $24 \mathrm{~h}$. The set-up allowed the respirometer to be in two states: "disconnected" and "connected" (Fig. 1B).

We used optical sensors (fibre-optic oxygen microsensors) to record the oxygen partial pressure in the water (Klimant et al. 1997). Optical oxygen sensors (also called oxygen optodes) have important advantages over common Clark type electrodes: they are extremely small (the tip size range from $<30 \mu \mathrm{m}$ to $2 \mathrm{~mm}$ ); they do not consume oxygen; their signal is not influenced by the flow rate, salinity, and $\mathrm{pH}$ of the water; they are insensitive to electrical interferences and magnetic fields. Therefore, they are perfect oxygen sensors to work with in flow-through respirometers. The oxygen meters MICROX8 (PreSens, Germany) with eight fibre-optic oxygen microsensors (PreSens, Germany) were calibrated in advance of the measurements with solutions containing oxygen at $0 \%$ (saturated solution of $\mathrm{Na}_{2} \mathrm{SO}_{3}$ ) and at $100 \%$ air saturation (aquarium water). All calibration solutions were temperature equilibrated in the experimental tank. The calibration procedure has been carried out right before the measurements took place.

The water temperature was raised by $3{ }^{\circ} \mathrm{C}$ each night and oxygen uptake was measured during daytime in the temperature range between $3{ }^{\circ} \mathrm{C}$ and $24{ }^{\circ} \mathrm{C}$. Measurements with warm-acclimated animals were started at $12{ }^{\circ} \mathrm{C}$ and additional analyses with an additional set of warm-acclimated fishes were carried out at temperatures below $12{ }^{\circ} \mathrm{C}$.

An aquarium pump and a peristaltic pump (Fig. 1B) were used to create water flow through the respirometer. After baseline oxygen levels had been monitored the respirometer was connected and water flow was adjusted (by means of the peristaltic pump) to a level that prevented oxygen partial pressure at the outlet of the respirometer from falling below $75 \%$ of incoming values (Fig. 2B). This precaution was taken in order to avoid hypoxic exposure of $Z$. viviparus. Oxygen concentration in the excurrent water of the respirometer was monitored as a function of time (once in $30 \mathrm{~s}$; PreSens Software) during 1.5-2 h (phase 3, Fig. 2B). Then the respirometer was disconnected and the baseline recorded again to check for potential drift of the optodes (Fig. 2B).

The rate of oxygen consumption was calculated according to Eqs. 4, 5, 6, a combination of Dalton's (for moist air) and Henry's laws (Ultsch et al. 1980).
$\mathrm{Po}_{2}=0.2095\left(P_{b}-P_{\mathrm{H}_{2} \mathrm{O}}\right)[\mathrm{kPa}]$

$\left[O_{2}\right]_{i}=P_{2} \times \alpha_{O_{2}} \quad\left[\mu\right.$ moles litre $\left.{ }^{-1}\right]$

$M o_{2}=\frac{\left(\left[\mathrm{O}_{2}\right]_{i}-\left[\mathrm{O}_{2}\right]_{e}\right) \times f r}{w_{f}}\left[\mu\right.$ moles $\left.\min ^{-1} \mathrm{~g}^{-1}\right]$

where: $\mathrm{Po}_{2}$ partial oxygen pressure in air $(\mathrm{kPa}) ; 0.2095$ fraction of oxygen in air; $P_{b}$ air barometric pressure on the day of measurement $(\mathrm{kPa}) ; P_{H_{2} O}$ partial pressure of water vapour in air $(\mathrm{kPa})$, considering temperature; $\left[\mathrm{O}_{2}\right]_{i}$ oxygen concentration in incurrent water ( $\mu$ moles litre ${ }^{-1}$ ) (phase 1 or 4 "baseline" in Fig. 2B); $\alpha_{O_{2}}$ solubility coefficient for oxygen in water $\left(\mu\right.$ moles litre $\left.{ }^{-1} \mathrm{kPa}^{-1}\right)$ as it depends on temperature and water salinity; $\left[\mathrm{O}_{2}\right]_{e}$ averaged (for the period of measurement, phase 3 in Fig. $2 \mathrm{~B}$ ) oxygen concentration in excurrent water $\left(\mu\right.$ moles $\left.1^{-1}\right)$, calculated as the percent fraction of incurrent (baseline) oxygen concentration; $f r$ rate of the water flow through the respirometer $\left(1 \mathrm{~min}^{-1}\right) ; w_{f}$ weight of the fish $(\mathrm{g}) . \mathrm{Mo}_{2}$ was expressed as $\mu$ moles of oxygen consumed within a minute per gram of fish body and normalized for $100 \mathrm{~g}$ fish body ( $\mu$ moles $\left.\min ^{-1} 100 \mathrm{~g}^{-1}\right)$.

The typical data set of the $\mathrm{Mo}_{2}$ measurement and the sequence of operational steps are shown in Fig. 2B. The fishes were exposed to a temperature change of $3{ }^{\circ} \mathrm{C}$ per night starting from acclimation temperatures. They stayed in the respirometers during the whole experimental period and were not fed during the analyses.

\section{Statistical analysis}

Prior to any statistical analysis the rate specific results were normalized to $100 \mathrm{~g}$ fish weight in each experimental group according to Sokal and Rohlf (1995).

Prior to any statistical tests, normal distribution and homogeneity of variance of the data were estimated using a KolmogorovSmirnov test from GraphPad InStat V3.05. Statistical treatments were performed using standard one-way ANOVA (GraphPad InStat V3.05) and repeated-measures two-way ANOVA (Statistica V5.1) tests. We used Tukey's post-hoc comparisons to compare all pairs of variance with unequal $n$. Differences were considered significant when probability levels were less than 0.05 .

Both correlation and multiple linear regression analyses were performed using GraphPad InStat V3.05. Two-phase linear regression analyses were performed according to recommendations of Motulsky (1999), the regression model was introduced into GraphPad Prism V3.0 for analysis. Non-linear regression analyses to fit oxygen consumption data were performed using an exponential growth model (GraphPad Prism V3.0). Highest $\mathrm{R}^{2}$, smallest absolute sum of squares (ASS) and smaller numbers of equation components were main criteria of the quality of the fit by the various regression models (Motulsky 1999).

We used an $F$-test to compare entire curves of temperaturedependent rates of oxygen consumption according to Motulsky (1999) (GraphPad Prism V3.0) and an unpaired $t$-test was used to compare best-fit values of non-linear regression variables.

\section{Results}

\section{Morphological data}

We did not find significant differences (one-way ANOVA, $P>0.05$ ) in morphological data (weight, length) between populations (North Sea, Baltic Sea, Norwegian Sea), $(n=132)$, therefore, the morphological data from all studied populations were pooled and presented in Fig. 3. 


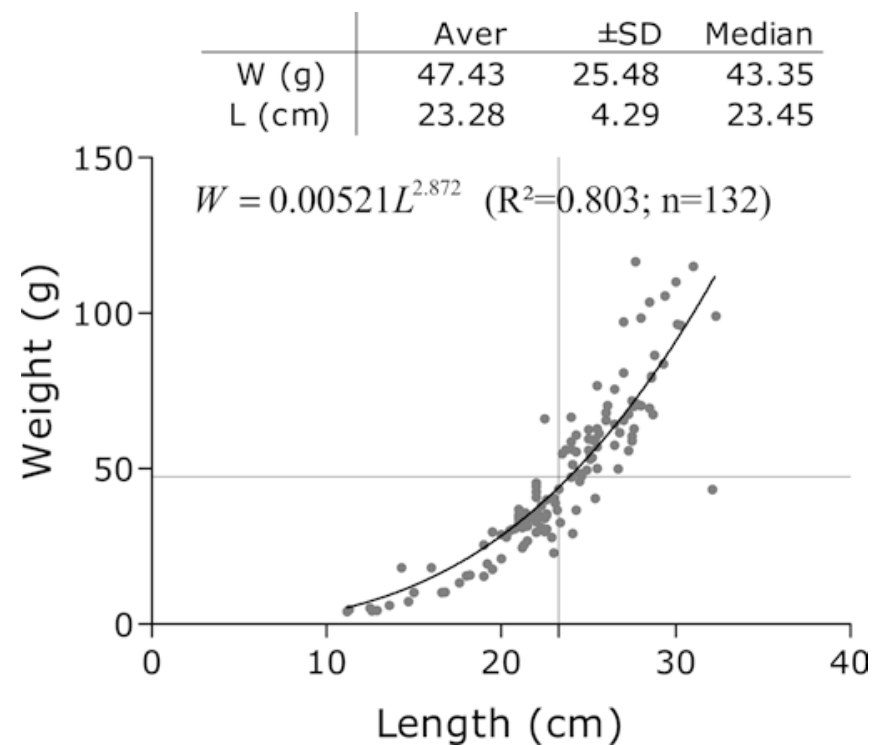

Fig. 3 Morphological data of common eelpout (Zoarces viviparus). The broken lines indicate the means of the corresponding parameters

\section{Critical thermal maxima}

LE is a less reliable parameter to record CTMax than OS in the case of eelpout, because of the bottomdwelling lifestyle of the fish (visual observation). Normally, eelpouts are lying on the bottom and use pectoral fins and body bending to maintain balance; therefore, LE was not well expressed in some cases even if it took place. In contrast, OS was always very clear. There was a very significant (repeated measures two-way ANOVA, $P<0.01$ ) difference between these parameters (LE and OS) in both populations. Repeated measures two-way ANOVA analysis (Table 2) also showed that there was no significant difference $(P>0.05)$ in LE and OS between the two populations from North and Baltic Seas. We did not find a significant $(P>0.05)$ heat hardening effect in both parameters for the two populations when comparing the consecutive CTMax measurements during 5 days (repeated measures two-way ANOVA). The only exception was in the case of OS of Baltic eelpout on the second day of measurements (Table 2), however, this significant increase could not be verified on the consecutive days. Therefore, we have discarded this data point as it probably represents a fluctuation. There was no correlation between CTMax and fish weight $(P>0.05)$. Thus, there was no significant difference in CTMax between North Sea and Baltic Sea populations.

Progressive changes in the behavioural response to an acute temperature increment $\left(1{ }^{\circ} \mathrm{C} \mathrm{min}{ }^{-1}\right)$ are compiled in Table 3. Typically, behavioural changes in the eelpout consist of several quite clear steps: (1) anxiety: the fish starts to show agitated behaviour, (2) fin up: the fish erects the pectoral fin, (3) active swimming: the fish starts to move actively, (4) attempt to escape: the fish tries to jump out of the aquarium, (5) LE, and (6) OS. Data are pooled from both populations (Baltic and North Sea) and all measurements, since no heat hardening and no significant differences between Baltic and North Sea populations were observed.

\section{Critical oxygen concentration}

For maintained experimental conditions we checked the relationship between Fiv of the closed respirometer and time to extreme hypoxia at $12{ }^{\circ} \mathrm{C}$. It is very important to maintain the time to extreme hypoxia to be able to clearly detect the transition from oxyregulation to oxyconformity. There was a very significant positive correlation between Fiv and time to extreme hypoxia $(r=0.856$, $P<0.01, n=27)$, which is described by a linear relationship: Fiv $=0.904+0.0734$ time $\left(R^{2}=0.823 ; n=27\right)$, where time is the time to extreme hypoxia (min). Using Fiv values of $14-16\left(\right.$ at $\left.12{ }^{\circ} \mathrm{C}\right)$ and a temperature correction factor of $+2.5 \%$ of the initial volume of the respirometer per $1{ }^{\circ} \mathrm{C}$ temperature increment the inside volume of the closed respirometer was successfully adjusted such that each individual fish reached extremely hypoxic conditions within 3-3.5 hours at any temperature.

The $\left[\mathrm{O}_{2}\right]_{\mathrm{c}}$ was measured between $12{ }^{\circ} \mathrm{C}$ and $18.5^{\circ} \mathrm{C}$ only for eelpout from the Baltic population acclimated to $12{ }^{\circ} \mathrm{C}$. We could not go beyond $18.5^{\circ} \mathrm{C}$, as the eelpouts died at higher temperatures.

It is necessary to point out that eelpouts recovered extremely well after exposure to extremely hypoxic conditions. Right after the measurements the fish were

Table 2 Critical thermal maxima (CTMax) measured as loss of equilibrium (LE) and/or onset of spasms (OS) for Baltic Sea $(\mathrm{m}=44.0 \pm 12.2 \mathrm{~g})$ and North Sea $(\mathrm{m}=9.9 \pm 3.1 \mathrm{~g})$ eelpouts, which were acclimated to $12^{\circ} \mathrm{C}$

\begin{tabular}{|c|c|c|c|c|c|c|c|c|}
\hline \multirow[t]{2}{*}{ Time of measurement (h) } & \multicolumn{4}{|l|}{ Baltic } & \multicolumn{4}{|l|}{ North Sea } \\
\hline & $\mathrm{LE} \pm \mathrm{SD}\left({ }^{\circ} \mathrm{C}\right)$ & $n$ & $\mathrm{OS}\left({ }^{\circ} \mathrm{C}\right) \pm \mathrm{SD}$ & $n$ & $\mathrm{LE} \pm \mathrm{SD}\left({ }^{\circ} \mathrm{C}\right)$ & $n$ & $\mathrm{OS} \pm \mathrm{SD}\left({ }^{\circ} \mathrm{C}\right)$ & $n$ \\
\hline 0 & $25.7 \pm 1.2$ & 7 & $28.0 \pm 1.0$ & 7 & $27.1 \pm 0.9$ & 5 & $29.1 \pm 0.2$ & 5 \\
\hline 24 & $27.1 \pm 1.0$ & 6 & $29.1 \pm 0.6^{* *}$ & 6 & $26.4 \pm 0.2$ & 2 & $28.8 \pm 1.1$ & 5 \\
\hline 48 & $27.2 \pm 0.5$ & 4 & $28.8 \pm 0.9$ & 6 & $25.4 \pm 0.8$ & 3 & $28.4 \pm 1.1$ & 4 \\
\hline 72 & $27.4 \pm 0.5$ & 6 & $28.8 \pm 0.8$ & 6 & $26.3 \pm 1.5$ & 4 & $28.5 \pm 1.4$ & 4 \\
\hline 96 & $27.0 \pm 0.9$ & 5 & $28.6 \pm 1.1$ & 6 & $27.5 \pm 0.6$ & 3 & $29.1 \pm 0.5$ & 4 \\
\hline Average & $26.8 \pm 1.1$ & - & $28.7 \pm 0.9$ & - & $26.6 \pm 1.1$ & - & $28.8 \pm 0.9$ & - \\
\hline
\end{tabular}

\footnotetext{
** Difference is significant from control $(0 \mathrm{~h} ; P<0.01)$
} 
Table 3 Progressive changes in the behavioural responses of Zoareces viviparus to a progressive rapid temperature increase $\left(1{ }^{\circ} \mathrm{C}\right.$ $\mathrm{min}^{-1}$ ). Data from both populations (Baltic and North Sea) and all measurements are pooled, for reference see Table 2. Values are means $\pm \mathrm{SD}(n)$. Anxiety: the fish starts to show agitated behaviour; Fin up: the fish erects the pectoral fin; Active swimming: the fish starts to move actively; Attempt to escape: the fish tries to jump out of the aquarium

Temperature $\left({ }^{\circ} \mathrm{C}\right)$

Acclimation temperature

Anxiety

12

Fin up

$18.8 \pm 2.2(42)$

Active swimming

$20.1 \pm 2.0(44)$

Attempt to escape

$22.1 \pm 2.0(31)$

$23.6 \pm 2.0(17)$

$26.7 \pm 1.1(45)$

OS

very quiescent; however, after $2-3 \mathrm{~h}$ their usual behaviour was restored. To ensure that post-hypoxic recovery was more or less complete the fish were allowed to rest for $48 \mathrm{~h}$ after each $\left[\mathrm{O}_{2}\right]_{\mathrm{c}}$ measurement.

A typical data set of $\left[\mathrm{O}_{2}\right]_{\mathrm{c}}$ and $\mathrm{Mo}_{2}$ obtained by closed respirometry is presented in Fig. 2A. The correlation analysis reveals that there is an extremely significant positive correlation $(P<0.001)$ between rate of oxygen consumption, critical oxygen concentration and temperature (Table 4). The relationship between $\mathrm{Mo}_{2}$ and $\left[\mathrm{O}_{2}\right]_{\mathrm{c}}$ is linear (Fig. 6) and the following run test showed that there is no a significant departure from linearity $(P>0.05)$. The multiple linear regression analysis (GraphPad InStat V3.05) of data revealed that the relationship between $\left[\mathrm{O}_{2}\right]_{\mathrm{c}}, \mathrm{Mo}_{2}$ and temperature is also described by linear equation:

$$
\begin{aligned}
& {\left[\mathrm{O}_{2}\right]_{c}=21.698+11.998 \mathrm{Mo}_{2}+1.166 \mathrm{~T}} \\
& \left(R^{2}=0.417, n=29, P<0.001\right)
\end{aligned}
$$

where $\left[\mathrm{O}_{2}\right]_{c}$ critical oxygen concentration $(\mu \mathrm{M}) ; \mathrm{Mo}_{2}$

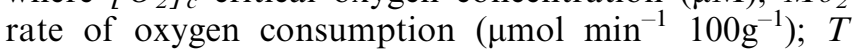
estimation temperature $\left({ }^{\circ} \mathrm{C}\right)$.

The temperature dependencies of $\mathrm{Mo}_{2}$ is described by exponential curve (Table 5); consequently the temperature dependence of $\left[\mathrm{O}_{2}\right]_{\mathrm{c}}$ is also describes by exponential curve (Fig. 8). These equations display a relatively low $R^{2}$ value, due to high scattering of the data over a relatively short temperature interval $\left(12-18.5^{\circ} \mathrm{C}\right)$. However, statistical comparison analyses $\left(R^{2}\right.$; absolute sum

Table 4 Matrix of correlation coefficients for rate of oxygen con-

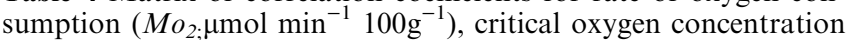
$\left(\left[\mathrm{O}_{2}\right]_{c} \mu \mathrm{M}\right)$ and measuring temperature (between $12{ }^{\circ} \mathrm{C}$ and $\left.18.5^{\circ} \mathrm{C}\right)$

$$
\left[\begin{array}{lll}
\left.\mathrm{O}_{2}\right]_{\mathrm{c}} & \mathrm{Mo}_{2} & \text { Measuring } \\
\text { temperature }
\end{array}\right.
$$

\begin{tabular}{lccc}
\hline $\left.\mathrm{O}_{2}\right]_{\mathrm{c}}$ & 1.0000 & $0.6877^{*}$ & $0.6310^{*}$ \\
$\mathrm{Mo}_{2}$ & $0.6877^{*}$ & 1.0000 & $0.5367^{*}$ \\
Measuring temperature & $0.6310^{*}$ & $0.5367^{*}$ & 1.0000 \\
\hline
\end{tabular}

$* P<0.001$

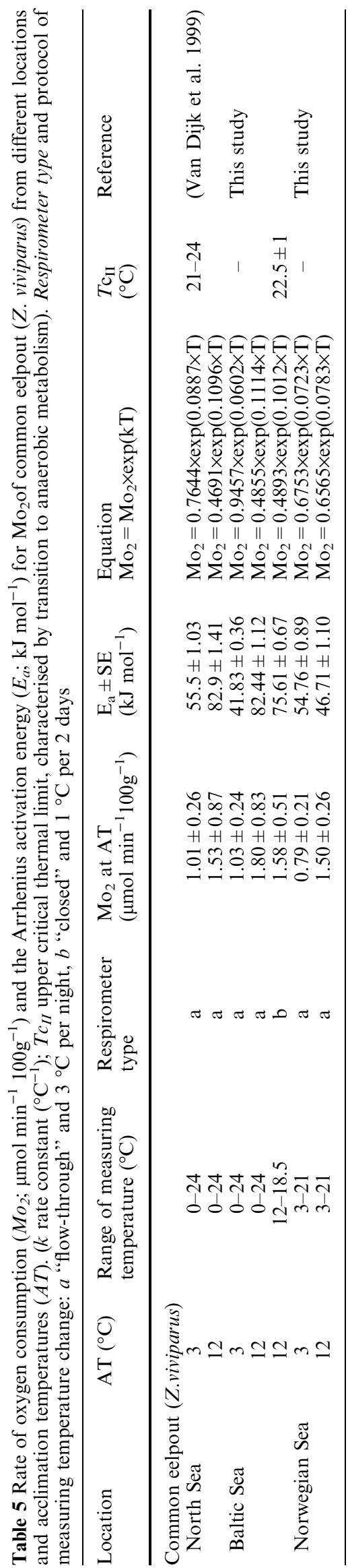


of square; standard deviation of the residuals) revealed that the chosen functions are the best to fit the data.

\section{Rate of oxygen consumption}

The comparison of methodological approaches to measure $\mathrm{Mo}_{2}$ and its temperature dependence (closed respirometry with a temperature change by $1{ }^{\circ} \mathrm{C}$ per 2 days versus flow-through respirometry with a temperature change by $3{ }^{\circ} \mathrm{C}$ per night) did not reveal significant differences ( $F$-test, $P<0.05$; Table 5 and Fig. 4$)$.

Oxygen consumption rates of cold-acclimated $\left(3{ }^{\circ} \mathrm{C}\right)$ and warm-acclimated $\left(12^{\circ} \mathrm{C}\right) \mathrm{Z}$. viviparus from different locations are presented in Fig. 5 and Table 5. The analysis includes data for North Sea eelpout obtained from Van Dijk et al. (1999; Fig. 1a). At low temperatures $\mathrm{Mo}_{2}$ of cold-acclimated Z. viviparus from North Sea and Baltic Sea were significantly (50-60\%) higher than those of warm-acclimated eelpout acutely exposed to low temperature (Fig. 5A, B). Oxygen consumption of warm-acclimated eelpout from North Sea and Baltic Sea showed a more rapid increase with temperature than $\mathrm{Mo}_{2}$ of cold-acclimated eelpout from the same location. Accordingly, the Arrhenius activation energy for oxygen consumption was higher for warm- than for cold-acclimated eelpout (Table 5). However, we did not observe such effects in Norwegian eelpout (Fig. 5C), where no difference between acclimation groups was visible. Moreover, the levels of $\mathrm{Mo}_{2}$ of both cold- and warmacclimated Norwegian eelpouts were similar to those of $\mathrm{Mo}_{2}$ of cold-acclimated Baltic Sea eelpout (Table 5). The comparison of $\mathrm{Mo}_{2}$ levels among all cold-acclimated eelpouts from the different locations revealed no difference between populations at temperatures less than $13-15{ }^{\circ} \mathrm{C}$; however, at high temperatures $\left(>13-15{ }^{\circ} \mathrm{C}\right)$

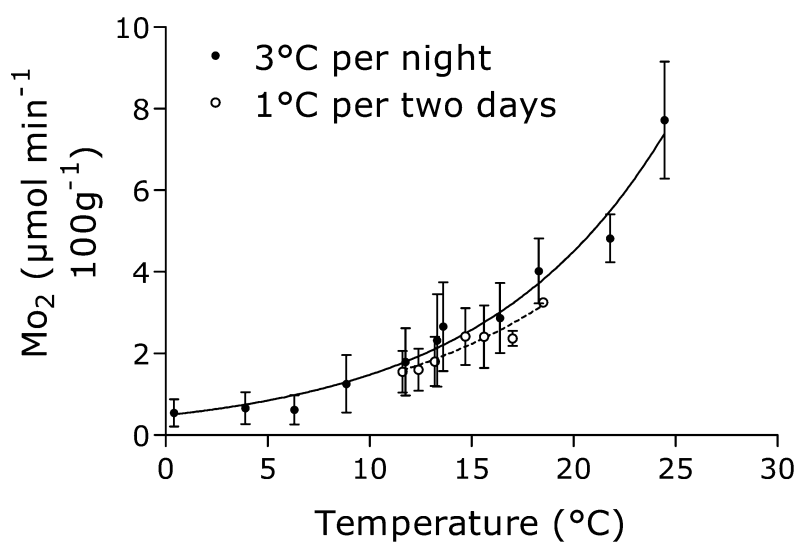

Fig. 4 Comparison of the protocols of temperature change and experimental set-ups exemplified in $12{ }^{\circ} \mathrm{C}$-acclimated common eelpout (Z. viviparus) from the Baltic Sea. The $\mathrm{Mo}_{2}$ in the flowthrough respirometer (filled circles, solid curve) was measured at a temperature change of $3{ }^{\circ} \mathrm{C}$ per night $(n=8)$, whereas the $\mathrm{Mo}_{2}$ in the closed respirometer (empty circles, broken curve) was measured at a temperature change of $1{ }^{\circ} \mathrm{C}$ per 2 days $(n=7)$. Salinity was $17 \%$. Values are means \pm SD. See also Table 5 cold-acclimated North Sea specimens displayed significantly higher levels of $\mathrm{Mo}_{2}$ than those from the Baltic and Norwegian Seas. The comparison of $\mathrm{Mo}_{2}$ among all warm-acclimated eelpouts from different locations, again, showed no difference between populations at temperatures less than $13-15{ }^{\circ} \mathrm{C}$; however, at high temperatures $\left(>13-15^{\circ} \mathrm{C}\right)$ Norwegian eelpout displayed significantly lower $\mathrm{Mo}_{2}$ values than their North Sea and
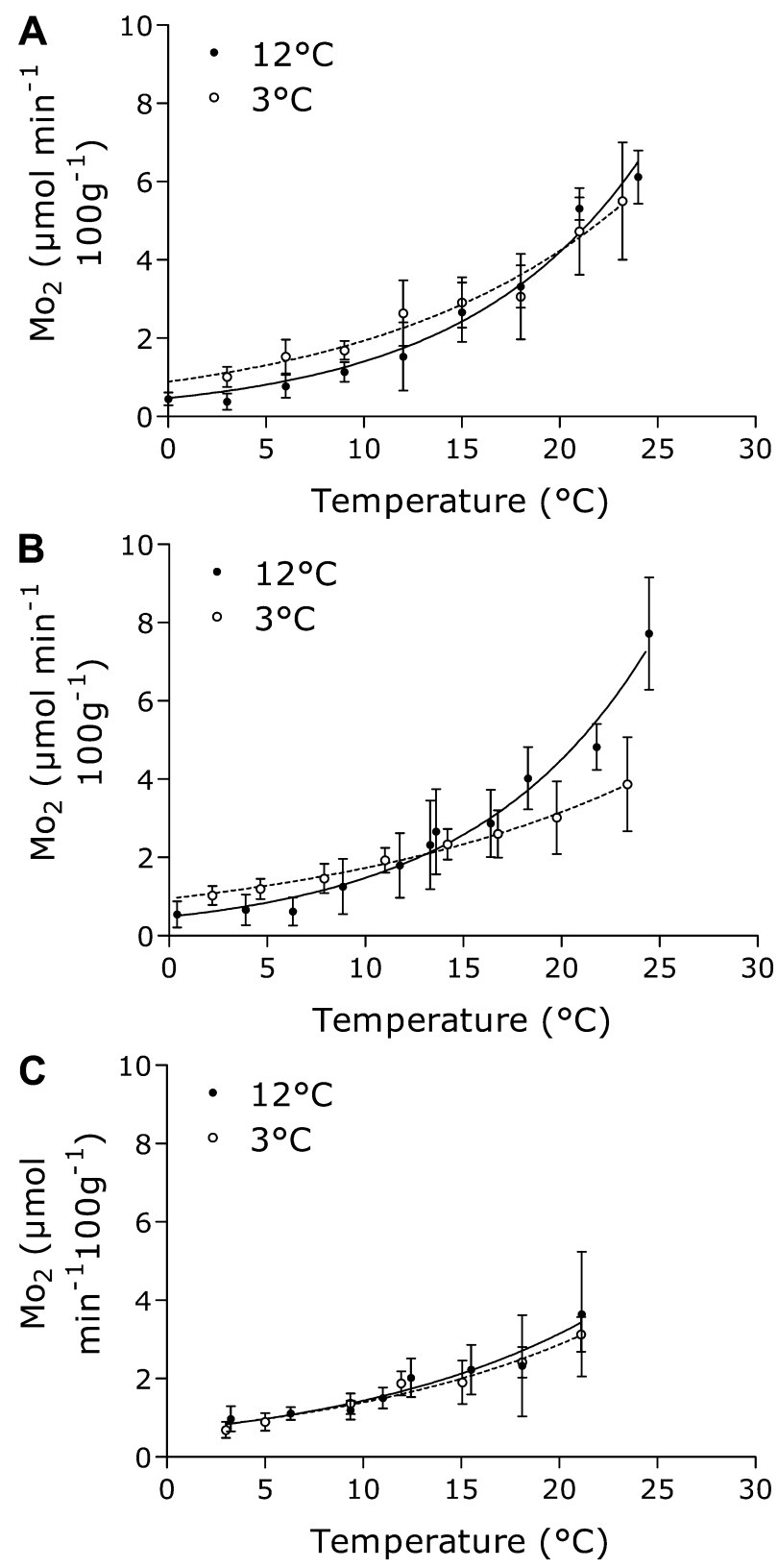

Fig. 5A-C $\mathrm{Mo}_{2}$ of common eelpout (Z. viviparus) from the North Sea (A), Baltic Sea (B) and Norwegian Sea (C) measured in a flowthrough respirometer. The rate of temperature increase was $3{ }^{\circ} \mathrm{C}$ per night, salinity $33 \%$ for North and Norwegian Seas and $17 \%$ for Baltic Sea animals. Filled circles fitted with a solid curve were obtained from $12{ }^{\circ} \mathrm{C}$-acclimated fishes, whereas unfilled circles fitted with a broken curve originate from $3{ }^{\circ} \mathrm{C}$-acclimated fishes. Values are means $\pm \mathrm{SD}(n=7-8)$. Data for North Sea eelpout were adopted from Van Dijk et al. (1999). See also Table 5 
Baltic conspecifics. Arrhenius plots of $\mathrm{Mo}_{2}$ of all experimental groups revealed linear slopes and no break over the investigated temperature range (runs test; $P>0.05)$.

An unpaired $t$-test of non-linear regression variables [ $a$ and $b$ for $y=a \times \exp (\mathrm{bx})$ ] revealed a general trend for variables to change over the course of temperature acclimation (Table 5). In the case where the temperature profile of $\mathrm{Mo}_{2}$ changed after acclimation to low temperature $\left(3{ }^{\circ} \mathrm{C}\right)$, the quantitative variable $(a)$ of the regression equation became significantly higher $(P<0.05)$, but, at the same time, the qualitative variable (b) of the regression equation became significantly lower $(P<0.05)$. This observation applied to eelpout from North and Baltic Seas, but not to Norwegian eelpout.

\section{Discussion}

\section{Acclimation temperature}

Acclimation temperatures of $3{ }^{\circ} \mathrm{C}$ and $12{ }^{\circ} \mathrm{C}$ were chosen in order to cover the natural temperature range of the species. $3{ }^{\circ} \mathrm{C}$ reflects the winter period, $12{ }^{\circ} \mathrm{C}$ is quite close to the optimal temperature for somatic growth of eelpout, which is $13-14{ }^{\circ} \mathrm{C}$ (recalculated from data in Fonds et al. 1989). The optimal temperature for somatic growth was determined on the basis of growth experiments: daily growth in body length $\left(\mathrm{mm} \mathrm{day}^{-1}\right)$, daily weight increments in ash-free dry weight (mg AFD day $\left.{ }^{-1}\right)$ and daily weight increment in energy $\left(\mathrm{J} \mathrm{day}^{-1}\right.$ ) (Fonds et al. 1989). We did not use higher acclimation temperatures (above $18{ }^{\circ} \mathrm{C}$ ), because eelpout have a lower survival rate during long-term acclimation at temperatures above $18{ }^{\circ} \mathrm{C}$ (M. Zakhartsev, personal observation); moreover, eelpout have an upper lethal temperature of about 22-23 ${ }^{\circ} \mathrm{C}$ (Fonds et al. 1989).

\section{Critical thermal maximum}

The analysis of CTMax is classified as a dynamic method to evaluate thermal tolerance limits, unlike the determination of $\mathrm{LT}_{50}$, which is a static method (Lutterschmidt and Hutchison 1997b). Therefore, the value of CTMax depends on the experimental protocol (rate of temperature increment and acclimation temperature). The heating rate of $1{ }^{\circ} \mathrm{C} \mathrm{min}-1$ was chosen according to Lutterschmidt and Hutchison (1997b), because with a faster protocol $\left(>1{ }^{\circ} \mathrm{C} \mathrm{min}^{-1}\right)$, lag-periods between changes in body and water temperature may interfere. On the other hand, a slower protocol $\left(<1{ }^{\circ} \mathrm{C} \mathrm{min}^{-1}\right)$ might result in the interference of acclimation effects (for instance, changes in protein synthesis). Since the CTMax protocol does not relate to a direct ecological interpretation (Lutterschmidt and Hutchison 1997a, 1997b) it can be used only as a value for comparative physiological study. Our measurements did not reveal any differences between two eelpout populations (North Sea and
Baltic Sea) despite quite significant differences in their environmental conditions (seasonal temperature range and salinity, Table 1). This means that the physiological mechanisms, which are setting the limits for acute temperature resistance (CTMax), have identical properties in both populations, despite of all environmental differences.

We did not observe any heat hardening effect despite daily heat exposure (for 5 consecutive days of CTMax measurements). This may indicate that in eelpout the rate of the expression of heat protective mechanisms (heat shock proteins, changes in protein synthesis etc) is quite slow or absent. These findings may suggest that eelpout prefer to live in a more or less stable environment with little daily temperature fluctuations. However, the behavioural response of eelpout to acute temperature increments $\left(1{ }^{\circ} \mathrm{C} \min ^{-1}\right.$; Table 3$)$ shows that $12-{ }^{\circ} \mathrm{C}$ acclimated fishes do not respond to acute warming until the temperature reaches $18{ }^{\circ} \mathrm{C}$. This means that the warm-acclimated fish can tolerate such acute temperature elevations.

\section{Comparison of respirometer types and protocols}

We used two different respirometry methods, which led to similar results (Fig. 4 and Table 5), despite the different approaches to calculate $\mathrm{M}_{\mathrm{O} 2}$ (Eqn. 3 versus Eqns. 4, 5, 6; Table 5). Data obtained by closed respirometry $\left(\left[\mathrm{O}_{2}\right]_{\mathrm{c}}\right.$ and $\mathrm{Mo}_{2}$ for a narrower temperature range) perfectly match the data collected in the flowthrough respirometer $\left(\mathrm{Mo}_{2}\right.$ for a broader temperature range). However, there was a difference in mortality: when temperature was increased by $1{ }^{\circ} \mathrm{C}$ per 2 days all fish died at $18.5^{\circ} \mathrm{C}$, whilst with a temperature change of $3{ }^{\circ} \mathrm{C}$ per night they could survive up to $24{ }^{\circ} \mathrm{C}$. The repeated exposure to extreme hypoxia and subsequent recovery possibly explains the enhanced mortality during the closed respirometry experiments. As animals likely exceed pejus temperatures and experience a loss in aerobic scope beyond $14-15{ }^{\circ} \mathrm{C}$ (due to capacity limitations of the circulatory system; C. Bock, F. Sartoris, H.O. Pörtner, unpublished data), increased mortality between pejus and critical temperatures may result from enhanced oxidative stress which is already enhanced when temperature-induced functional hypoxia sets in (Pörtner 2002a, 2002b) and which likely becomes aggravated when high temperature and hypoxic exposures are combined.

\section{Rate of oxygen consumption}

Oxygen consumption rates of eelpout from different locations were investigated in order to reveal adaptive differences in metabolic rates. As shown earlier (Van Dijk et al. 1999) the eelpout, as a carnivorous sit-andwait predator, is mainly inactive with extremely little spontaneous activity. Therefore, the measured oxygen 
consumption rate $\left(\mathrm{Mo}_{2}\right)$ can be considered equivalent to standard metabolic rate (SMR). For this particular reason, the eelpout is a perfect animal model for respiratory studies.

In all populations oxygen demand increased in an exponential way with rising temperature (Fig. 5), with no instantaneous metabolic rate compensation. Our oxygen uptake measurements revealed no difference in SMR between $12{ }^{\circ} \mathrm{C}$-acclimated Baltic and North Sea populations (Table 5). A compensatory rise in the SMR of cold-acclimated $\left(3{ }^{\circ} \mathrm{C}\right)$ Baltic and North Sea eelpouts occurred compared to warm-acclimated $\left(12^{\circ} \mathrm{C}\right)$ fish (Fig. 5A, B). In contrast, Norwegian eelpout did not at all display warm-acclimated metabolic rates (Fig. 5C) but kept their SMR (at both acclimation temperatures) at the level corresponding to cold-acclimated Baltic eelpout. This may indicate that the SMR of Norwegian eelpout is permanently adjusted to life in the cold. This population probably does not encounter large temperature variations during seasonal or daily cycles, due to life in deep and cold Norwegian fjords.

There was a general tendency for a decrease in Arrhenius activation energy $\left(E_{a}\right)$ of SMR as a result of acclimation to low temperature (Table 5, from 80-90 kJ $\mathrm{mol}^{-1}$ to $40-47 \mathrm{~kJ} \mathrm{~mol}^{-1}$ ). This drop was accompanied by a partial compensatory rise in SMR levels at low temperature. However, this was not the case for Norwegian eelpout. A change in $E_{a}$ suggests that the changes in oxygen uptake go hand in hand with changes in the kinetic properties of the oxygen consuming biochemical machinery. The fact that Norwegian eelpout did not show such changes may indicate their inability to adjust to warm temperatures above $13-15^{\circ} \mathrm{C}$.

According to Table 5, acclimation to low temperature results in an increased $\mathrm{M}_{\mathrm{O} 2}$ at $0{ }^{\circ} \mathrm{C}\left(\mathrm{Mo}_{2}{ }^{\circ}\right)$ and decreased rate constant $(k)$. Change of $\mathrm{Mo}_{2}{ }^{\circ}$ indicates that the fish aerobic metabolism underwent quantitative changes. At the same, decrease of $k$ and consequently $\mathrm{E}_{\mathrm{a}}$ indicated qualitative changes in the aerobic metabolism. The observation is in line with literature findings that the number of mitochondria that participate in oxygen consumption increases in the cold, but at the same time their kinetic properties remained suppressed by low temperature. Thus, in the course of acclimation to the cold, the aerobic metabolism undergoes only quantitative compensatory change.

Comparative analysis of temperature dependence of $\mathrm{Mo}_{2}$ among populations showed that all populations are indistinguishable at temperatures below $13-15{ }^{\circ} \mathrm{C}$. These temperatures coincide with the pejus temperature observed in a separate study (see above), but the cause and effect relationships remain obscure.

Very little is known about the genetic homogeneity of eelpout along the range of distribution. We found only one comprehensive research of eelpout population along Danish waters (there are a number of publications dedicated to population genetics of Zoarces by Hjorth, Simonsen, Frydenberg, Gyldenholm, Chrisitansen published in Hereditas over the period between 1971 and
1988). These authors (Frydenberg and Simonsen 1973) found that the most of the eelpouts' loci $(28-31 \%)$ are polymorphic. The Zoarces population in the Danish belts is subdivided into smaller units with a restricted level of genetic exchange (Hjorth and Simonsen 1975). In Mariager Fjord (Denmark) even local populations $10 \mathrm{~km}$ apart have been found to be genetically distinct (Christiansen et al. 1981). Associated variations in morphological characters were kept virtually unchanged for more than 60 years (Christiansen et al. 1988). This genetic background in combination with the non-migratory behaviour of eelpout suggests that all studied populations (North Sea, Baltic Sea and Norwegian Sea) are to some extent genetically isolated, due to very limited gene exchange between "settlements". Such genetic differences may be linked to the functional differences (differences in oxygen consumption) observed in this study.

\section{Critical oxygen concentration}

A time span of 3-3.5 h has been chosen for $\left[\mathrm{O}_{2}\right]_{\mathrm{c}}$ measurements, because within this time we were able to get a clear hypoxia-induced hypometabolic response (transition from oxyregulation to oxyconformity which may include transition to anaerobic metabolism; Boutilier and St-Pierre 2000). A faster protocol did not provide us with a clear picture of transition from oxyregulation to oxyconformity, possibly owing to the depletion of internal oxygen stores. The slower protocol caused the fish to stay under hypoxia for quite a long time; therefore some fishes did not survive this protocol.

The eelpout is a clear metabolic regulator (oxyregulator), because $\mathrm{Mo}_{2}$ is independent on oxygen concentration (Fig. 2A) within a certain range of ambient oxygen concentrations. The $\left[\mathrm{O}_{2}\right]_{\mathrm{c}}$ is the oxygen concentration in water where $\mathrm{Mo}_{2}$ in an oxyregulator becomes dependent on ambient oxygen concentration (Herreid 1980; Ultsch et al. 1980) and a metabolic machine switches on anaerobic energy production; such transition is exemplified in many cases (Pörtner and Grieshaber 1993). Accordingly, $\left[\mathrm{O}_{2}\right]_{c}$ is the oxygen concentration when diffusion of oxygen to mitochondria begins to limit oxidative phosphorylation. However, anaerobic ATP production can only temporarily meet the sustained energy demands of the various cellular ATP consuming processes. Shortage of substrates and accumulation of deleterious end products (Van Dijk et al. 1999; Zielinski et al. 2000) set temporal constraints on anaerobiosis as a long-term solution to severe oxygen limitation (Boutilier and St-Pierre 2000).

According to Herreid (1980), $\mathrm{Mo}_{2}$ is a function of oxygen availability and total oxygen conductance throughout the body:

$$
\begin{aligned}
& M o_{2}=G_{T}\left(P_{i} o_{2}-P_{m} o_{2}\right) \\
& \frac{1}{G_{T}}=\sum\left(\frac{1}{G_{V}}+\frac{1}{G_{G}}+\frac{1}{G_{B}}+\frac{1}{G_{C}}+\ldots\right)
\end{aligned}
$$


where $P_{i} O_{2}$ is incoming, environmental oxygen partial pressure $(\mathrm{kPa}) ; P_{m} \mathrm{O}_{2}$ is oxygen partial pressure in mitochondria $(\mathrm{kPa}) ; G_{T}$ is total oxygen conductance $\left(1 \mathrm{~min}^{-1} 100 \mathrm{~g}^{-1}\right) ; G_{V}$ is oxygen conductance due to ventilation; $G_{G}$ is oxygen conductance across the gill surface; $G_{B}$ is oxygen conductance via the circulation including cardiac output and respiratory pigment affinities; $G_{C}$ is oxygen conductance of the cellular membrane and cytoplasm. Thus, oxygen consumption can remain constant in a situation of declining $P_{\mathrm{i}} \mathrm{O}_{2}$ (i.e. hypoxia) only if the conductance of oxygen flow increases and there is indeed a number of mechanisms to fulfil this precondition (increasing ventilation, increasing blood circulation, etc.; Frederich and Pörtner 2000). However, all of these mechanisms have certain limits of functional capacity. To support an increasing functioning of $\mathrm{G}_{\mathrm{T}}$ an animal also needs adequate energy supply, which sooner or later will become limiting, last not least due to the limited use of anaerobic energy production (discussed above).

$\mathrm{Mo}_{2}$ and $\left[\mathrm{O}_{2}\right]_{\mathrm{c}}$ can be considered as physiologically coupled parameters, because there is a very significant correlation between them $(r=0.6877, P<0.001)$ that is described by linear equations (Fig. 6; Eqn. 7). The level of $\mathrm{Mo}_{2}$ is the temperature-modulated variable (Table 5), which sets the level of $\left[\mathrm{O}_{2}\right]_{\mathrm{c}}$. It is obvious that the higher the oxygen demand, the higher the oxygen concentration at which the above-mentioned constraints for anaerobic energy production and total oxygen conductance will set in.

The $\left[\mathrm{O}_{2}\right]_{\mathrm{c}}$ was defined by Herreid (1980) as a function of two variables, $\mathrm{Mo}_{2}$ and $\mathrm{G}_{\mathrm{T}}$ :

$\left[O_{2}\right]_{c}=\frac{M o_{2}}{G_{T}}$

Therefore, $\left[\mathrm{O}_{2}\right]_{\mathrm{c}}$ will rise whenever aerobic metabolism increases, and it will fall whenever oxygen conductance rises (Herreid 1980). Our data are in line with this consideration (Fig. 6; Eqn. 7). These relationships

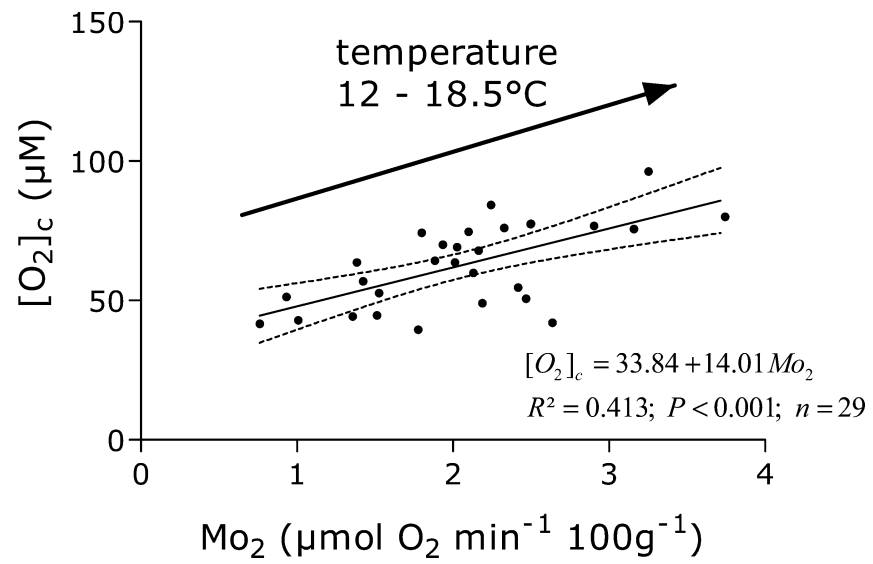

Fig. 6 Correlated changes in the $\mathrm{Mo}_{2}\left(\mu\right.$ moles $\left.\min ^{-1} 100 \mathrm{~g}^{-1}\right),\left[\mathrm{O}_{2}\right]_{\mathrm{c}}$ $(\mu \mathrm{M})$, and temperature $\left({ }^{\circ} \mathrm{C}\right)$ for common eelpout (Z. viviparus) from the Baltic population (salinity $=17 \%$ ) acclimated to $12{ }^{\circ} \mathrm{C}$ $(n=7)$. The rate of temperature change was $1{ }^{\circ} \mathrm{C}$ per 2 days

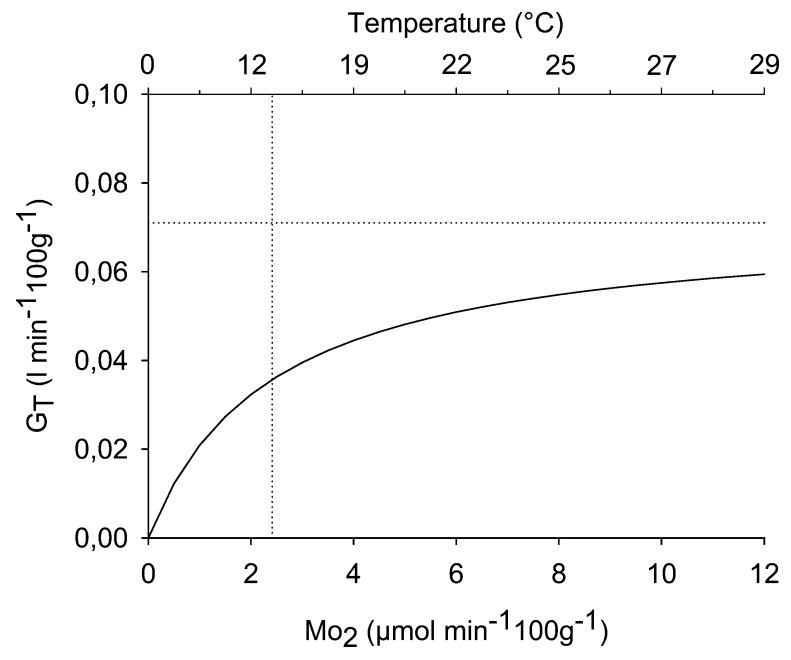

Fig. 7 Theoretical approximation of the relationship between total oxygen conductance ( $G_{T}$; definition according to Eqn. 9) and $\mathrm{Mo}_{2}$ for $12{ }^{\circ} \mathrm{C}$-acclimated Baltic eelpout (for $\mathrm{Mo}_{2}$ between $0{ }^{\circ} \mathrm{C}$ and $24{ }^{\circ} \mathrm{C}$; Fig. 5B). The $\mathrm{G}_{\mathrm{T}}$ reaches saturation level at $0.0711 \mathrm{~min}^{-1}$ $100 \mathrm{~g}^{-1}$ and half-saturation at $2.36 \mu \mathrm{mol} \mathrm{m^{-1 }} 100 \mathrm{~g}^{-1}$ of $\mathrm{Mo}_{2}$. Warm-acclimated eelpouts reach this level of $\mathrm{Mo}_{2}$ at $14.2{ }^{\circ} \mathrm{C}$. It means that at temperatures above $14-15^{\circ} \mathrm{C}$ the metabolic capacity to shift $\left[\mathrm{O}_{2}\right]_{\mathrm{c}}$ to lower values by increasing $\mathrm{G}_{\mathrm{T}}$ (Eqn. 10) will be restricted

(Fig. 6; Eqn. 10) allow us to estimate roughly how big the range of variability is for $\mathrm{G}_{\mathrm{T}}$. First of all, according to Eqn. 10 and due to the linear relationship between $\mathrm{Mo}_{2}$ and $\left[\mathrm{O}_{2}\right]_{\mathrm{c}}$ (Fig. 6), the relationship between $\mathrm{Mo}_{2}$ and $\mathrm{G}_{\mathrm{T}}$ is described by a hyperbolic equation which reaches saturation. For an $\mathrm{Mo}_{2}$ between $0 \mu \mathrm{mol} \mathrm{min}{ }^{-1}$ $100 \mathrm{~g}^{-1}$ and $10 \mu \mathrm{mol} \mathrm{min}{ }^{-1} 100 \mathrm{~g}^{-1}$ (corresponding to a temperature range between $0{ }^{\circ} \mathrm{C}$ and $25^{\circ} \mathrm{C}$ for $12{ }^{\circ} \mathrm{C}$ acclimated Baltic eelpout) it yields a maximum, saturated level of $G_{\mathrm{T}}$ at $0.0711 \mathrm{~min}^{-1} 100 \mathrm{~g}^{-1}$ and a level of half-saturation at $2.36 \mu \mathrm{mol} \mathrm{min}^{-1} 100 \mathrm{~g}^{-1}$ of $\mathrm{Mo}_{2}$ (Fig. 7). This is the level of $\mathrm{Mo}_{2} 12{ }^{\circ} \mathrm{C}$-acclimated Baltic eelpout reaches approximately at $15{ }^{\circ} \mathrm{C}$. This means that at $15{ }^{\circ} \mathrm{C}, 50 \%$ of the full capacity of the total gas conductance of Baltic eelpout is already used and at temperatures above $15{ }^{\circ} \mathrm{C}$, the metabolic capacity to shift $\left[\mathrm{O}_{2}\right]_{\mathrm{c}}$ to low enough values by means of increasing $\mathrm{G}_{\mathrm{T}}$ will become more limited. This theoretical approximation is in line with experimental observations and explained by a progressive limitation of aerobic scope and, thus, the oxygen limitation of thermal tolerance. In parallel with a warm-induced rise in oxygen demand, harsh environmental conditions, which may be combined with high temperature exposure (high salinity and low barometric pressure), will result in a further reduction of oxygen concentrations in water and will enhance oxygen limitation for the eelpout. Finally, the warminduced rise in $\left[\mathrm{O}_{2}\right]_{\mathrm{c}}$ will approach the environmental oxygen concentration indicating complete loss of aerobic scope (Fig. 8). At this point, the $\left[\mathrm{O}_{2}\right]_{\mathrm{c}}$ corresponds, by definition, to the upper critical temperature $\left(T \mathrm{c}_{\mathrm{II}}\right)$, which is characterized by transition to anaerobic metabolism (see above, (Pörtner 2001, 2002a, 2002b; 


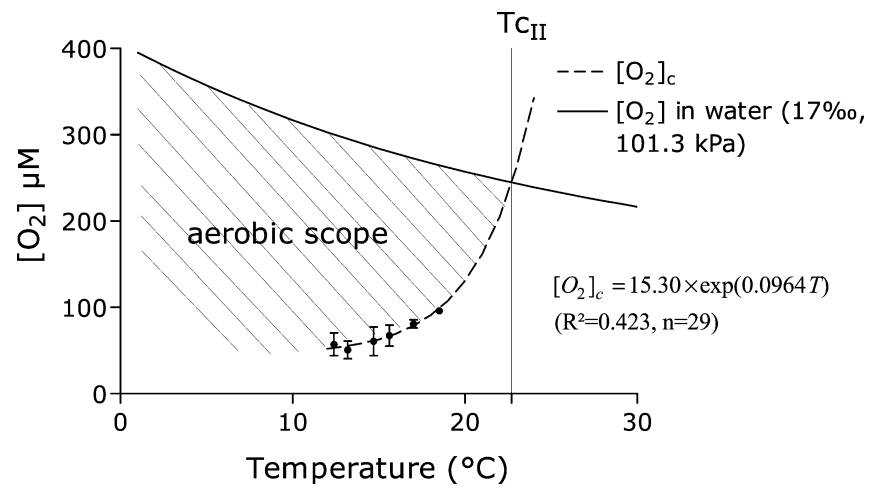

Fig. 8 The scope for aerobic metabolism (shaded area) is dependent on temperature, water salinity, and barometric pressure. The concentration of dissolved oxygen in water (solid curves) decreases with temperature, while the critical oxygen concentration $\left(\left[\mathrm{O}_{2}\right]_{c}\right)$ (filled circles fitted by broken curve) increases in exponential way. The upper critical temperature $\left(T c_{I I}\right)$ is set at temperatures where two of these curves intersect. Consequently an animal is forced to switch over to anaerobic metabolism. This example is given for eelpout from Baltic Sea. Unfavourable combinations with high salinity and low barometric pressure $(33 \%, 90 \mathrm{kPa})$ will shift the $T \mathrm{c}_{\text {II }}$ further down. Values of $\left[\mathrm{O}_{2}\right]_{\mathrm{c}}$ are means $\pm \mathrm{SD}$

Pörtner and Grieshaber 1993; Sommer et al. 1997; Van Dijk et al. 1999). According to an extrapolation from Fig. 8, the $\left[\mathrm{O}_{2}\right]_{\mathrm{c}}$ for Baltic eelpout reaches the natural oxygen level in Baltic sea water $(17 \%, 101.3 \mathrm{kPa})$ at a temperature of $22.5 \pm 1{ }^{\circ} \mathrm{C}$, corresponding to $250 \mu \mathrm{M}$ of oxygen (Fig. 8). Low barometric pressure and high water salinity will shift this thermal limit to even lower temperatures.

Our calculations perfectly match the conclusions of Van Dijk et al. (1999) who found that, for Z. viviparus, the upper critical temperature limit (" $T \mathrm{c}_{\mathrm{II}}$; characterised by the onset of anaerobic metabolism, evidenced by the accumulation of lactate and succinate") is located between $21{ }^{\circ} \mathrm{C}$ and $24{ }^{\circ} \mathrm{C}$ (Table 5). Fonds et al. (1989) also found that mortality of the eelpout was rather high at temperatures above $20{ }^{\circ} \mathrm{C}$. They concluded that the upper lethal limit for $Z$. viviparus probably lies close to $22-23{ }^{\circ} \mathrm{C}$. Our data are in line with these earlier observations and demonstrate that for water breathing ectothermic animals, the $T \mathrm{c}_{\mathrm{II}}$ is the same as the temperature where $\left[\mathrm{O}_{2}\right]_{\mathrm{c}}$ meets ambient oxygen concentration (Fig. 8). At the $T \mathrm{c}_{\mathrm{II}}$, due to capacity limitation of the oxygen delivery system, the animals face a mismatch between oxygen demand and oxygen availability. This phenomenon results in transition into hypoxia and, possibly, a hypometabolic phase that is time-limited. Accordingly, behavioural avoidance of such temperatures should result, with the consequence that bio-geographical distribution of this species becomes limited.

\section{Conclusions}

We have summarised the key events in the thermal physiology of eelpout (Z. viviparus) in Table 6, considering both data from this study and the literature. The

Table 6 Key events in thermal physiology of common eelpout Z. viviparus

\begin{tabular}{|c|c|c|c|}
\hline $\begin{array}{l}\text { Temperature } \\
\left({ }^{\circ} \mathrm{C}\right)\end{array}$ & Description & $\begin{array}{l}\text { Rate of temperature } \\
\text { change }\left(\Delta \mathrm{T}^{\circ} \mathrm{C} / \Delta \mathrm{t}\right)\end{array}$ & Reference \\
\hline$<0$ & Lower temperature limit for growth & $\begin{array}{l}\text { Growth experiment } \\
\text { (28-36 day at fixed } \\
\text { temperature) }\end{array}$ & (Fonds et al. 1989) \\
\hline 4 & Avoidance temperature during winter & Natural & $\begin{array}{l}\text { Personal communication } \\
\text { G. Naevdal (University } \\
\text { of Bergen, Norway) }\end{array}$ \\
\hline $13-14$ & Optimal temperature for somatic growth & - & (Fonds et al. 1989) \\
\hline$>13-15$ & $\begin{array}{l}\text { The difference in } \mathrm{Mo}_{2} \text { among populations } \\
\text { becomes expressed above this temperature }\end{array}$ & $3^{\circ} \mathrm{day}^{-1}$ & This study \\
\hline$\sim 15$ & $\begin{array}{l}\text { Total gas conductance }\left(\mathrm{G}_{\mathrm{T}} ; 1 \mathrm{~min}^{-1} 100 \mathrm{~g}^{-1}\right) \\
\text { through the eelpout body becomes used on } \\
50 \% \text { of full capacity and further increments } \\
\text { of } \mathrm{G}_{\mathrm{T}} \text { will be restricted }\end{array}$ & Theoretical approximation & This study \\
\hline 18 & Avoidance temperature during summer & Natural & $\begin{array}{l}\text { Personal communication } \\
\text { G. Naevdal (University } \\
\text { of Bergen, Norway) }\end{array}$ \\
\hline 18.5 & High mortality & $\begin{array}{l}1^{\circ} \mathrm{C} \text { day }^{-1}, \text { combined with } \\
\text { frequent hypoxia }\end{array}$ & This study \\
\hline$>20$ & High mortality & $\begin{array}{l}\text { Growth experiment } \\
\text { (28-36 day at fixed } \\
\text { temperature) }\end{array}$ & (Fonds et al. 1989) \\
\hline $21-24$ & $\begin{array}{l}\mathrm{Tc}_{\mathrm{II}} \text { upper critical temperature (onset of } \\
\text { anaerobic metabolism) }\end{array}$ & $3^{\circ} \mathrm{C}_{\text {day }}{ }^{-1}$ & (Van Dijk et al. 1999) \\
\hline $22.5 \pm 1$ & $\mathrm{Tc}_{\mathrm{II}}\left(\right.$ intersection of the $\left[\mathrm{O}_{2}\right]_{\mathrm{c}}$ with ambient $\left.\left[\mathrm{O}_{2}\right]\right)$ & $1^{\circ} \mathrm{C} \mathrm{day}^{-1}$ & This study \\
\hline $22-23$ & Upper lethal temperature limit & $\begin{array}{l}\text { Growth experiment } \\
\text { (28-36 day at fixed } \\
\text { temperature) }\end{array}$ & (Fonds et al. 1989) \\
\hline$>24$ & High mortality & $3^{\circ} \mathrm{C}$ day $^{-1}$ & (Van Dijk et al. 1999) \\
\hline
\end{tabular}


traditional method of analysing the limits of thermal tolerance shows ecologically irrelevant temperatures $\left(28.8^{\circ} \mathrm{C}\right)$. With increasing temperature, standard metabolic rate rises in an exponential way. At the same time, the scope for aerobic metabolism becomes gradually decreased beyond pejus temperatures $\left(13-15^{\circ} \mathrm{C}\right)$ and is finally lost when the $\left[\mathrm{O}_{2}\right]_{\mathrm{c}}$ reaches water oxygen levels (at $22.5 \pm 1{ }^{\circ} \mathrm{C}$ for Baltic eelpout), e.g. at critical temperatures, where animals are forced to switch over to anaerobic metabolism. At this point, energy demands no longer match energy production and as a result survival becomes time-limited and depends on the capacity of anaerobic metabolism.

The capacity limitation of the oxygen delivery system probably sets the first physiological limit for survival in the warm. The upper pejus temperatures for the eelpout $\left(13-15^{\circ} \mathrm{C}\right)$ are close to average temperature maxima in the natural habitat, thereby limiting latitudinal distribution of the species. The critical temperature likely correlates with species distribution, but will be relevant only at temperature extremes and is only tolerated passively. For short-term survival at more extreme temperatures, possibly experienced in the shallow water of the Wadden Sea, the elevated hypoxia tolerance of $Z$. viviparus may become important.

Acknowledgements A contribution to the ELOISE project: Effect of climate induced temperature change on marine coastal fishes (CLICOFI), funded by the European Union program "Climate and environment", contract No. ENV4-CT97-0596. The experiments comply with the current laws of the Belgium and Germany.

\section{References}

Babkov AI (1982) A short hydrological characteristic of Chupa Inlet in the White Sea. In: Kulakowski EE (ed) Ecological investigations of species perspective for aquaculture in the White Sea. Zoological Institute Leningrad, Leningrad, USSR, pp 94-98

Bohnecke G, Dietrich G (1951) Monatskarten der Oberflächentemperaturen for die Nord - und Ostsee und die angrenzenden Gewässer. Hamburg, Deutscher Hydrographisches Institut Hamburg

Boutilier RG, St-Pierre J (2000) Surviving hypoxia without really dying. Comp Biochem Physiol A 126:481-490

Brodte E (2001) Wachstum und Fruchtbarkeit der Aalmutterarten Zoarces viviparus (Linn?) und Pachycara brachycephalum (Pappenheim) aus unterschiedlichen klimatischen Regionen. Fach Biologie University Bremen, Alfred-Wegener-Institut f?r Polar- und Meeresforschung, Bremerhaven

Christiansen FB, Nielsen BV, Simonsen V (1981) Genetical and morphological variation in the eelpout Zoarces viviparus. Can J Genet Cytol 23:163-172

Christiansen FB, Nielsen VH, Simonsen V (1988) Genetics of Zoarces populations. 15. Genetic and morphological variation in Mariager Fjord. Hereditas 109:99-112

Cossins AR, Bowler K (1987) Temperature biology of animals. Chapman and Hall, London

Fischer P, Rademacher K, Kils U (1992) In situ investigations on the respiration and behaviour of the eelpout Zoarces viviparus under short-term hypoxia. Mar Ecol Prog Ser 88:181-184

Fonds M, Jaworski A, Iedema A, Puyl PVD (1989) Metabolism, food consumption, growth and food conversion of shorthorn sculpin (Myoxocephalus scorpius) and eelpout (Zoarces viviparus). I. C. E. S., Demersal Fish Committee G:31:1-10
Frederich M, Pörtner HO (2000) Oxygen limitation of thermal tolerance defined by cardiac and ventilatory performance in spider crab, Maja squina. Am J Physiol Reg Int Comp Physiol 279:R1531-R1538

Frydenberg O, Simonsen V (1973) Genetics of Zoarces populations. 5. Amount of protein polymorphism and degree of genic heterozygosity. Hereditas 75:221-231

Herreid CF (1980) Hypoxia in invertebrates. Comp Biochem Physiol A 67:311-320

Hjorth JP, Simonsen V (1975) Genetics of Zoarces populations. 8. Geographic variation common to the polymorphic loci $\mathrm{HbI}$ and EstIII. Hereditas 81:173-184

Johnston IA (1985) Temperature adaptation of enzyme function in fish muscle. In: Laverack MS (ed) Physiological adaptations of marine animals. Company of Biologists, pp 95-122

Johnston IA, Walesby NJ (1977) Molecular mechanisms of temperature adaptation in fish myofibrillar adenosine triphosphates. J Comp Physiol B 119:195-206

Klimant I, Kuhl M, Glud RN, Holst G (1997) Optical measurement of oxygen and temperature in microscale: strategies and biological applications. Sensors Actuators 38-39 B:29-37

Kristoffersson R, Oikari A (1975) Notes on the biology of the eelpout, Zoarces viviparus ( L.), in the brackish water of Tvärminne, Gulf of Finland. Annales zoologici fennici 12:143-147

Lutterschmidt WI, Hutchison VH (1997a) The critical thermal maximum: data to support the onset of spasms as the definitive end point. Can J Zool 75:1553-1560

Lutterschmidt WI, Hutchison VH (1997b) The critical thermal maximum: history and critique. Can J Zool 75:1561-1574

Motulsky H (1999) Analyzing data with GraphPad Prism. GraphPad Software, San Diego, Calif.

O'Brien J, Dahlhoff E, Somero GN (1991) Thermal resistance of mitochondrial respiration: hydrophobic interactions of membrane proteins may limit thermal resistance. Physiol Zool 64:1509-1526

Pörtner HO (2001) Climate change and temperature-dependent biogeography: oxygen limitation of thermal tolerance in animals. Naturwissenschaften 88:137-146

Pörtner HO (2002a) Climate variations and the physiological basis of temperature dependent biogeography: systemic to molecular hierarchy of thermal tolerance in animals. Comp Biochem Physiol A 132:739-761

Pörtner HO (2002b) Physiological basis of temperature-dependent biogeography: trade-offs in muscle design and performance in polar ectotherms. J Exp Biol 205:2217-2230

Pörtner HO, Grieshaber MK (1993) Critical $\mathrm{PO}_{2}(\mathrm{~s})$ in oxyconforming and oxyregulating animals: gas exchange, metabolic rate and the mode of energy production. In: Bicudo JEPW (ed) The vertebrate gas transport cascade: adaptations to environment and mode of life. CRC, Boca Raton, pp 330-357

Pörtner HO, Hardewig I, Sartoris FJ (1998) Energetic aspects of cold adaptation: critical temperatures in metabolic, ionic and acid-base regulation? In: Pörtner HO, Playle RC (eds) Cold ocean physiology. Cambridge University Press, Cambridge, pp $88-120$

Pörtner HO, Berdal B, Blust R, Brix O, Colozimo A, De Wachter B, Giuliani A, Johansen T, Fischer T, Knust R, Lannig G, Naevdal G, Nedenes A, Nyhammer G, Sartoris FJ, Serendero I, Sirabella P, Thorkildsen S, Zakhartsev MV (2001) Climate induced temperature effects on growth performance, fecundity and recruitment in marine fish: developing a hypothesis for cause and effect relationship in Atlantic cod (Gadus morhua) and common eelpout (Zoarces viviparus). Continental Shelf Res 21:1975-1997

Precht H, Chritophersen J, Hensel H, Larcher W (1973) Temperature and life. Springer, Berlin Heidelberg New York

Ross LG, Ross B (1999) Anaesthetic and sedative techniques for aquatic animals. Blackwell, Oxford

Shelford VE (1913) Animal communities in temperate America. The University of Chicago Press, Chicago

Sokal RR, Rohlf FJ (1995) Biometry. The principles and practice of statistics in biological research. W.H. Freeman, New York 
Sokolova IM, Pörtner HO (2001) Temperature effects on key metabolic enzymes in Littorina saxatilis and L. obtusata from different latitudes and shore levels. Mar Biol 139:113-126. DOI $10.1007 / \mathrm{s} 002270100557$

Sommer A, Klein B, Pörtner HO (1997) Temperature induced anaerobiosis in two populations of the polychaete worm Arenicola marina (L). J Comp Physiol B 167:25-35

Stoskopf MK (1992) Fish medicine. Saunders, Philadelphia

Ultsch GR, Ott ME, Heisler N (1980) Standard metabolic rate, critical oxygen tension, and aerobic scope for spontaneous activity of trout (Salmo gardneri) and carp (Cyprinus carpo) in acidified water. Comp Biochem Physiol A 67: 329-335
Van Dijk PLM, Tesch C, Hardewig I, Pörtner HO (1999) Physiological disturbances at critically high temperatures: A comparison between stenothermal antarctic and eurythermal temperate eelpouts (Zoarcidae). J Exp Biol 202:3611-3621

Yeager DP, Ultsch GR (1989) Physiological regulation and conformation: a BASIC program for the determination of critical points. Physiol Zool 62:888-907

Zielinski S, Lee PG, Pörtner HO (2000) Metabolic performance of the squid Lolliguncula brevis (Cephalopoda) during hypoxia: an analysis of the critical $\mathrm{Po}_{2}$. J Exp Mar Biol Ecol 243:241-259 